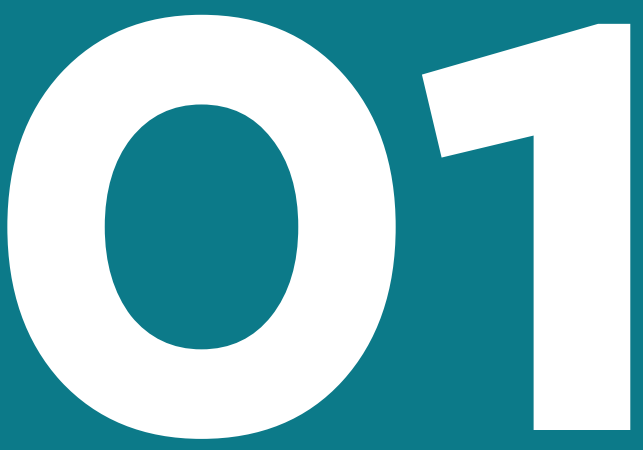

\title{
Insolvency analysis of the food manufacturing industry in Cuenca
}

Fecha de recepción: 29/08/2019

Fecha de aprobación: 24/01/2020 


\title{
Abstract
}

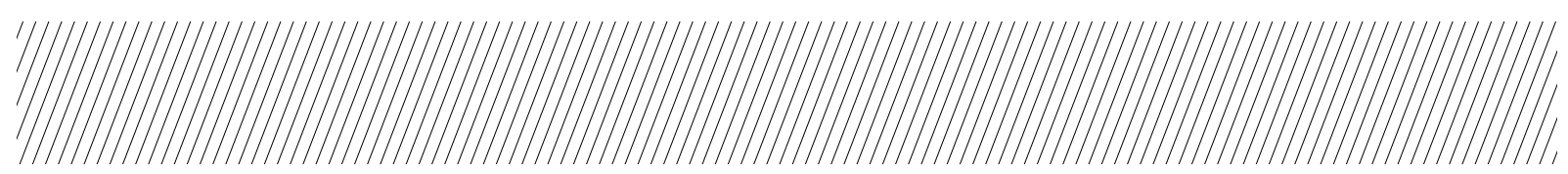

\author{
Iván Orellana Osorio ${ }^{1}$ \\ Marco Reyes Clavijo ${ }^{2}$ \\ Estefanía Cevallos Rodríguez ${ }^{3}$ \\ Luis Tonon Ordoñez ${ }^{4}$ \\ Luis Pinos Luzuriaga ${ }^{5}$
}

The risk of insolvency is related to failure or business closure, for this reason the analysis and management of this type of risk is important. The insolvency risk was applied to the food manufacturing industry in Cuenca in the period 2013-2017, which allowed to determine the bankruptcy risk existing in the companies analyzed, as well as trends of the indicator in relation to the business size. Two models were applied: the business insolvency prediction model of Altman and the logistic model using the maximum likelihood method proposed by Ohlson. Altman's model showed that companies in the 5 years analyzed are in "Safe Zone" (3,187 points in 2013 and 3,448 in 2017). Similarly, the Ohlson model, showed that in 2013 there was a 20,7\% risk of insolvency in the sector, compared to $17,7 \%$ in 2017 . The results of the analysis indicate that insolvency risk shows a decreasing trend in the analyzed period, which take us to the conclusion that the sector is financially healthy. However, due to the current changing environment and the internal operative management, it is very likely that the values suffer changes. Analyzing the risk of insolvency is fundamental for companies, considering that it will allow them to know the level of bankruptcy risk they have, and based on this, take measures to reduce the risk.

Key words:

Altman model; food sector in Cuenca; insolvency risk; Ohlson model.

Universidad del Azuay (ivano@uazuay.edu.ec)

Universidad del Azuay (mreyes@uazuay.edu.ec)

Universidad del Azuay (ecevallosr@uazuay.edu.ec)

Universidad del Azuay (Itonon@uazuay.edu.ec 


\section{Introduction}

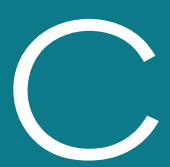

ontrary to what is thought, the oil sector is not the most important in the Ecuadorian economy. According to data from the Central Bank of Ecuador (2019) during the period studied, manufacturing is the most important sector of the economy with an average weighting of $12.32 \%$ of Gross Domestic Product (GDP) and together with construction, trade, agriculture and oil and Mines represent $50.09 \%$ of national production.

The Gross Value Added (GVA) shows the real contribution of manufacturing production. When analyzing the data contained in Table 1 , it is observed that the GVA generated in the province of Azuay represents an average contribution of $4.64 \%$ to Gross Domestic Product (GDP). In addition, because most of the business activity takes place in Cuenca, it is not surprising that its GVA represents on average $4.08 \%$ of GDP. It should be noted that according to projections made by National Institute of Statistics and Census (2019), Azuay is home to $5 \%$ of the national population. 
Table 1. Total GDP, Gross Value Added generated both in the province of Azuay and also in the city of Cuenca in millions of dollars

\begin{tabular}{|c|c|c|c|c|c|}
\hline Year & $\begin{array}{c}\text { Gross domes- } \\
\text { tic product }\end{array}$ & $\begin{array}{c}\text { Manufacturing } \\
\text { in Ecuador }\end{array}$ & $\begin{array}{c}\text { Total economy } \\
\text { of Azuay }\end{array}$ & $\begin{array}{c}\text { Manufactu- } \\
\text { ring in Azuay }\end{array}$ & $\begin{array}{c}\text { Total eco- } \\
\text { nomy of } \\
\text { Cuenca }\end{array}$ \\
\hline 2013 & $95.129,66$ & $11.974,29$ & $4.222,87$ & 762,94 & $3.728,34$ \\
\hline 2014 & $101.726,33$ & $13.716,74$ & $4.432,98$ & 798,56 & $3.949,72$ \\
\hline 2015 & $99.290,38$ & $13.512,95$ & $4.765,71$ & 828,47 & $4.172,77$ \\
\hline 2016 & $99.937,70$ & $13.592,34$ & $4.782,81$ & 842,42 & $4.190,83$ \\
\hline 2017 & $104.295,86$ & $13.866,08$ & $5.013,92$ & 840,33 & $4.392,84$ \\
\hline
\end{tabular}

Note. From "Documentos estadísticos.", by Central Bank of Ecuador (2018)
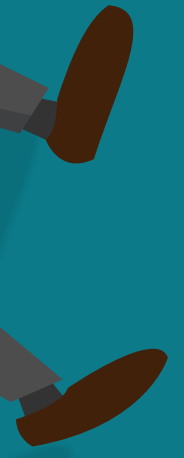

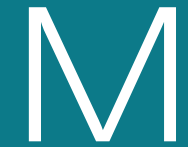

anufacturing in Azuay represents $19.95 \%$ of its economy, becoming one of the most important sectors of this province. In addition, it is estimated that around $4 \%$ of this percentage is generated by the food products manufacturing sector. The aforementioned justifies the importance of the present study (Central Bank of Ecuador, 2019).

In Ecuador, according to Martín (2017), the Chamber of Commerce of Quito reported that in 20167.641 companies were dissolved (6.300 more than in 2015); this situation is alarming, as it harms not only the owners, but the country's economy. Considering that companies are the engine of the economy of a country, the analysis of risks and returns (among which is the risk of insolvency) is very important, since it will allow to know in advance those companies that are at risk of bankruptcy The purpose of this research is to measure the levels of insolvency of companies in the food manufacturing industry in Cuenca. 


\section{Literature Review}

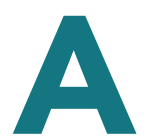

According to Echemendía (2011), the risk is the possibility of losing something or having an undesired, negative or dangerous result, situation where two components will intervene: the possibility or probability that a negative result will occur and the dimension of that result. Similarly, risk is related to finance; Bautista (2013) claims that uncertainty in finance brings consequences that usually tie the potential benefits to the possibility of losses. There is no way to access the opportunities without the danger of failure. Based on the aforementioned concept, it can be deduced that the risk will be present in any activity that is carried out, and on relation to the financial sphere.

Financial risk is defined as the uncertainty associated with the value and the return of a financial position. There are different types of financial risks and they can be classified as follows: interest rate risk, credit risk, market risk and exchange rate risk (Arias, Castaño, \& Rave, 2006). Risk management is important in order to predict events that affect the fulfillment of strategic business objectives.

Within the types of risk, insolvency or credit risk is one of the most important, since its management is related to the bankruptcy. Dichev (1998) claims that probability of bankruptcy is a natural proxy for firm distress. According to Wulandari, Norita y Iradianty (2014) bankruptcy is one of many things that is avoided by any company. By knowing the bankruptcy possibility, the company can make long-term plans, and anticipate to minimize the situation.

There are different models to predict bankruptcy and many scholars contributed to improve existing models. According to Pérez, Lopera y Vásquez (2017), bankruptcy risk models predict the probability that a company cannot meet the payment of its acquired obligations and therefore must cease operations. 
Paul FitzPatrick was one of the first investigators to analyze bankruptcy. Through his research called "Average ratios of twenty representative Industrial Failures", he analyzes the indicators of companies that have declared bankruptcy. In his research, the author describes the importance of the analysis of accounting indicators and the close relationship of the financial statements with the business. In addition, FitzPatrick says that ratios are useful tools in ascertaining the relationships, however, like all tools, ratios should be used only within the range of their efficient or appropriate use (FitzPatrick, 1932).

In later years, several authors have studied the risk of insolvency, among which are: Beaver (univariable analysis), Altman (multiple discriminant analysis) and Ohlson (logistic regression analysis), whose advantages, according to Calderón (2016) are:

- A different analysis methodology is used for comparison purposes.

- The methodologies are recognized worldwide

- The methodologies have application for companies that are not publicly traded.

Beaver studied business bankruptcy prediction and introduced univariate analysis techniques in order to determine the most relevant financial indicators to discriminate companies at risk of bankruptcy and non-bankruptcy. Beaver defines "Failure" as the inability of a firm to pay its financial obligations as they mature. The author also claims that a firm is said to have failed when any of the following events have occur in bankruptcy, bond default, an overdrawn bank account, or nonpayment of a preferred stock dividend (Beaver, 1966). 
Altman mentions that failing firms exhibit significantly different ratio measurements than continuing entities; in his work he compared a list of ratios individually for failed firms and a matched sample of nonfailed firms. Observed evidence for five years prior to failure was cited as conclusive that ratio analysis can be useful in the prediction of failure (Altman, 1968).

According to Pérez et al (2017) Altman introduces the discriminant analysis. From financial information, the author selects 5 ratios as the most relevant for the estimation of the Z-Score model, classifying as unbroken companies those that present a value $Z \geq 2.99$ and as broken those which have a value of $Z \leq 1,81$. The author calls companies that present $Z$ values between 1,81 and 2,99, "zone of ignorance", because in this interval there is a high probability of making classification errors. In addition, Altman et al. (1977) develop the ZETA® model, which unlike the Z-Score, includes market aspects, a concept of variance of the value of assets and share prices in the analyzes.

Ohlson (1980) introduces for the first time in this field the use of conditional logistic models. In his study, he builds 9 financial ratios to estimate 3 models, one to predict bankruptcy a year before, another to predict two years before and the other to predict one or two years before. From these it concludes that its correct classification percentage is of $96,12 \%, 95,55 \%$ and $92,84 \%$ respectively.

According to Ohlson (1980), it was possible to identify four basic factors as being statistically significant in affecting the probability of failure (within one year).

1. The size of the company.

2. A measure(s) of the financial structure.

3. A measure(s) of performance.

4. A measure(s) of current liquidity (the evidence regarding this factor is not as clear as compared to cases. 


\section{Model Z score of Altman}

Altman $(1968,2000)$ managed to classify five standard categories of indicators, including liquidity, profitability, leverage, solvency and profitability. The final discriminant function of Altman for manufacturing companies that are publicly negotiated is the following, according to Hernández (2014):

\section{$Z=1,2(X 1)+1,4(X 2)+3,3(X 3)+0,6(X 4)+0,999(X 5)$}

\section{Where:}

- $\mathrm{X} 1$ = Working capital / total assets.

- $\mathrm{X} 2$ = Retained earnings / total assets

- $\mathrm{X} 3$ = Profits before interest and taxes / total assets

- X4 = Market value of the equity / book value of the total debt

- $\mathrm{X} 5$ = Sales $/$ total assets

- $Z$ = Overall Index

X1: Working capital / total assets. - This ratio is a measure of the liquid net assets of a company, relative to the total capitalization, where the liquidity characteristics and size are related.

X2: Retained earnings / total assets. - Retained earnings is the account that contains the total amount of reinvested earnings and / or the losses of a company throughout its life. It is probable that a relatively young company shows a low ratio "Retained Earnings to Total Assets".

X3: Profits before interest and taxes / total assets. - This ratio is independent of factors such as taxes and the effect of financial leverage that a company presents. The power to generate profits from assets is measured. 
X4: Market value of the equity / book value of the total debt. - The market value of the equity is measured by the combination of the market value of all outstanding shares of the company, in the case of liabilities, the indicator includes short and long-term securities. The main weakness derives in the application of companies that do not publicly price their shares.
X5: Sales / total assets. - This ratio measures the ability to generate sales from the assets of the company, which is why it is considered as a measure of the ability of the administration to deal with competitive conditions.

\section{Adaptation of the model for private manufacturing companies}

Altman (2000) made a new estimate of the original model, substituting the book values of equity for the market value in $\times 4$. This variable that is available for any company that manages an accounting system.

The mentioned function is the following:

$Z^{\prime}=0,717(X 1)+0,847(X 2)+3,107(X 3)+0,420(X 4)+0,998(X 5)$

Where:

- X1 = Working capital / total assets.

- X2 = Retained earnings / total assets

- $\mathrm{X} 3=$ Profits before interest and taxes / total assets

- X4 = Book value of the equity / book value of the total debt

- X5 = Sales $/$ total assets

- $Z^{\prime}=$ Overall index 


\section{Adaptation of the model for private general companies}

According to Altman (2000) the model capable of predicting bankruptcies in non-manufacturing companies with closed capital in general (represented as $Z$ ") is the following:

$Z^{\prime \prime}=6,56(X 1)+3,26(X 2)+6,72(X 3)+1,05(X 4)$

Where:

- $\mathrm{X} 1$ = Working capital / total assets.

- $\mathrm{X} 2$ = Retained earnings / total assets

- $\mathrm{X} 3$ = Profits before interest and taxes / total assets

- X4 = Accounting value of the equity / book value of the total debt

- $Z^{\prime \prime}=$ Overall index

According to Hernández (2014), cut-off points or limits were established based on the discriminant functions and on the basis of the results of the $Z, Z$ 'and $Z$ "scores to be able to forecast potential bankruptcies. (See Table 2). 
Table 2. Cut points or limits of Altman Z scores

\begin{tabular}{c|c|c|c|}
\hline Prediction & $\begin{array}{c}\text { Public } \\
\text { Manufacturing } \\
\text { companies }\end{array}$ & $\begin{array}{c}\text { Private } \\
\text { Manufacturing } \\
\text { companies }\end{array}$ & $\begin{array}{c}\text { Non-Manufacturing } \\
\text { and foreign firms }\end{array}$ \\
\hline Distress zone & $<1,18$ & $<1,23$ & $<1,1$ \\
\hline Grey zone & 1,81 a 2,99 & 1,23 a 2,90 & 1,1 a 2,6 \\
Safe zone & $>2,99$ & $>2,90$ & $>2,6$ \\
\hline
\end{tabular}

Note. From "Modelo financiero para la detección de quiebras con el uso de análisis discriminante múltiple.", by Hernández (2014)

\section{Ohlson model}

Ohlson ( 1980) claims that the Multiple Discriminant Analysis (MDA) approach has been the most popular technique for bankruptcy studies using predictor vectors. However, there are some problems with these studies:

- The variance-covariance matrices of the predictors should be the same for both groups.

- The output of the application of an MDA model is a score which has little intuitive interpretation, since it is basically an ordinal ranking (discriminatory) device.

- There're also problems related to "matching" procedures which have been used in MDA. 
The use of conditional logit analysis, on the other hand, essentially avoids all of the problems discussed with respect to MDA.

According to Ordóñes y Reyna (2018), the logit expresses a value for the dependent variable, which is limited between zero and one:

$l(\beta)=\sum_{i E S_{1}} \log P\left(X_{i}, \beta\right)+\sum_{i E S_{2}} \log \left(1-\left(P\left(X_{i}, \beta\right)\right.\right.$

- $\beta=$ Vector of unknown parameters.

- $X_{i}=$ Vector of explanatory variables for observation $i, P(X i, \beta)$ as the probability of conditional break to $X_{i} y \beta$.

- $\mathrm{S}_{1}$ y $\mathrm{S}_{2}=$ Broken and unbroken companies

In order to estimate the insolvency risk-dependent behavior, based on the independent variables, the following logistic model is used, according to Ordóñez and Reyna (2018):

$$
\begin{aligned}
& \operatorname{logit}\left(P_{i t}\right)=\alpha-\beta_{1} \text { liq }_{i t}-\beta_{2} R_{N A} A_{i t}-\beta_{3} \text { ROA }_{i t}+\beta_{4} \text { EndAct }_{i t}+\beta_{5} \text { EndPatri }_{i t}- \\
& \beta_{6} \text { TEmpre }_{i t}+\beta_{7} \text { SectEcono }_{i t}-\beta_{8} \text { EdadEmp }_{i t}-\beta_{9} I P C_{i t}-\beta_{10} \text { CentrEcon }_{i t}+E_{i t}
\end{aligned}
$$




\section{Where:}

- $\quad \mathrm{i}=$ Information of the companies.

- $t=$ Period of the statistical sample (2013 al 2017).

- $\mathrm{X} 1_{\text {it }}=\operatorname{liq}$ (Current liquidity indicator $\frac{\text { current assets }}{\text { current liabilities }}$ )

- $\mathrm{X} 2_{\text {it }}=\mathrm{ROA}$ (Net profitability indicator of the asset $\frac{\text { net income }}{\text { total assets }}$ )

- $\mathrm{X} 3_{\text {it }}=\mathrm{ROE}$ (Profitability indicator $\frac{\text { net income }}{\text { equity }}$ )

- $\mathrm{X} 4_{\text {it }}=$ EndAct (Asset indebtedness indicator $\frac{\text { total liabilities }}{\text { total assets }}$ )

- $X 5_{i t}=$ EndPatri (Equity indebtedness indicator $\left.\frac{\text { total liabilities }}{\text { equity }}\right)$

- $\mathrm{X}_{\mathrm{it}}=\mathrm{TEmpre}$ (Business size 2013-2017, small, medium or large)

- $\mathrm{X}_{\text {it }}=$ SectEcono (Economic Sector 2013-2017, primary, secondary or tertiary)

- $\mathrm{X} 8_{i t}=$ EdadEmp (Age that the company has in the market, year of creation -year of study)

- $\quad X 9_{i t}=I P C^{1}$ (Index of perception of corruption)

- $\mathrm{X} 10_{i \mathrm{t}}=$ CentEcon $(0=$ outside the economic center; 1 = within the economic center)

1 The CPI classifies countries with a score between 0 (high levels of corruption) and 100 (low levels of corruption), based on the perception that the inhabitants have of the public sector (Tranparency International, 2018). 


\section{Data \& methodology}

\section{Approach, type and design of research}

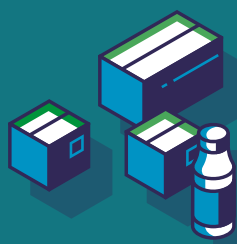

The study carried out in the research work was through a qualitative and quantitative approach. Based on information from scientific sources, issues associated with insolvency risk were investigated, as well as issues related to the manufacturing sector and its environment.

\section{Research technique}

A bibliometric analysis was carried out through the Publish or Perish program in order to obtain relevant information in the qualitative analysis, which helps to search and analyze the main academic sources for a given topic. The sources used are from texts, magazines, publications, statistical reports and reports from government institutions. With regard to the quantitative analysis, two methodologies were used to measure the insolvency of the food sector: Ohlson, which applies a model based on the maximum likelihood technique by logistic regression (logit), and Altman, which corresponds to a multiple discriminant analysis trough the Z Score model.

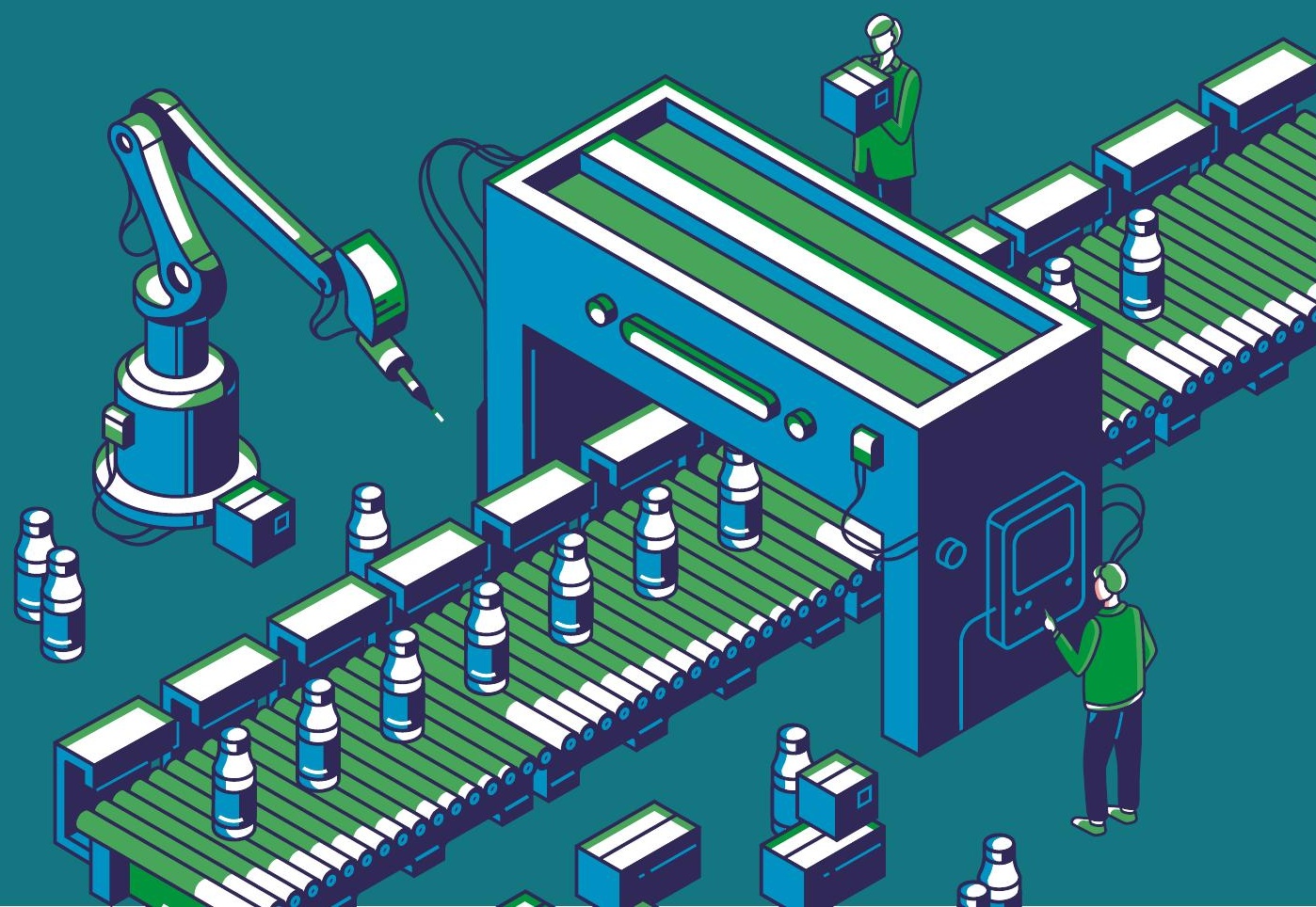




\title{
Data
}

Food manufacturing industry information - level CIIU 2

\author{
According to information from the Superintendence of \\ Companies (2018a), in the city of Cuenca there are a total of 45 \\ companies active in the food manufacturing industry. There is a \\ greater number of companies C1010 and C1030. (See Table 3)
}

Table 3. Classification of the food sector of Cuenca

\begin{tabular}{llc}
\hline \multicolumn{1}{c}{ CIIU } & \multicolumn{1}{c}{ Description } & Number of companies \\
\hline C1010 & Processing and preservation of meat & 10 \\
C1030 & Elaboration and conservation of fruits, vegetables and vegetables & 9 \\
C1050 & Production of dairy products & 4 \\
C1061 & Manufacture of grain mill products & 4 \\
C1071 & Manufacture of bakery. & 5 \\
C1072 & Preparation of sugar. & 1 \\
C1073 & Elaboration of cocoa, chocolate and confectionery products. & 2 \\
C1074 & Preparation of macaroni, noodles, alcuzcuz and similar farinaceous products. & 5 \\
C1079 & Preparation of other food products n.c.p. & 3 \\
C1080 & Preparation of prepared foods for animals. & 2 \\
\hline Total & & 45
\end{tabular}

Note. From "Portal de información", by Superintendence of Companies Securities and Insurance (2018)

The criteria for analyzing the financial information were the following:

- Companies that have 3 or more years of activity.

- Companies that have activity in the last year.

- Sales levels must be greater than $\$ 100,000$. 
Table 4. Sample of companies in the food manufacturing industry in Cuenca

\begin{tabular}{|c|c|c|}
\hline Company & CIIU & Workers \\
\hline ITALIMENTOS CÍA LTDA. & C1010 & 369 \\
\hline INDUSTRIA DE ALIMENTOS LA EUROPEA CÍA LTDA. & C1010 & 446 \\
\hline PIGGI'S EMBUTIDOS PIGEM CÍA LTDA. & C1010 & 174 \\
\hline DISTRIBUIDORA PERALTA ÁVILA & C1030 & 4 \\
\hline FRUTAS VEGETALES CARNES C LTDA FRUVECA & C1030 & 7 \\
\hline ALIMENTOS CHONTALAC CÍA LTDA. & C1050 & 45 \\
\hline LACTEOS MILKA LACMILK CÍA LTDA. & C1050 & 21 \\
\hline HELADOS LA TIENDA HELATIENDA CÍA LTDA. & C1050 & 16 \\
\hline PROALISUR CÍA LTDA. & C1061 & 26 \\
\hline $\begin{array}{l}\text { EL HORNO PANADERÍA Y PASTELERÍA ELHOPAPA CÍA } \\
\text { LTDA. }\end{array}$ & C1071 & 46 \\
\hline PASTIFICIO NILO C LTDA & C1074 & 27 \\
\hline PRODUCTOS TÍALUCCA CÍA LTDA. & C1074 & 14 \\
\hline BUENAÑO CAICEDO COMPAÑÍA DE NEGOCIOS S.A. & C1074 & 78 \\
\hline $\begin{array}{c}\text { MOLINO Y PASTIFICIO ALEXANDRA MOPALEX CÍA } \\
\text { LTDA. }\end{array}$ & C1074 & 15 \\
\hline PASTIFICIO TOMEBAMBA CÍA LTDA. & C1074 & 59 \\
\hline $\begin{array}{l}\text { ALIMENTOS ECUATORIANOS LOS ANDES S.A. } \\
\text { AEDESA }\end{array}$ & C1079 & 67 \\
\hline
\end{tabular}

Note. From "Portal de información", by Superintendence of Companies Securities and Insurance (2018) 


\section{Results}

\section{Financial situation analysis}

\section{Balance sheet of the food manufacturing industry - C10 companies}

Based on the information of the companies related in Table 8, the general balance of the analyzed period is described (2013-2017). (See Table 5).

Table 5. Balance sheet of the food manufacturing industry for the period 2013-2017

\begin{tabular}{|c|c|c|c|c|c|c|c|c|c|}
\hline Year & Asset & current asset & $\begin{array}{c}\text { Cash and cash } \\
\text { equivalents }\end{array}$ & Inventories & $\begin{array}{c}\text { Non-current } \\
\text { assets }\end{array}$ & Liabilities & $\begin{array}{c}\text { Current } \\
\text { liabilities }\end{array}$ & $\begin{array}{c}\text { Non-current } \\
\text { liabilities }\end{array}$ & Equity \\
\hline 2013 & $\$ 48.562 .575$ & $\$ 26.134 .707$ & \$ 3.633 .846 & $\$ 7.318 .772$ & $\$ 22.427 .868$ & $\$ 28.734 .405$ & $\$ 19.764 .014$ & \$ 7.797.218 & $\$ 19.828 .170$ \\
\hline 2014 & $\$ 55.190 .962$ & $\$ 28.959 .594$ & \$ 1.923 .868 & $\$ 10.703 .892$ & $\$ 26.231 .369$ & $\$ 33.059 .515$ & $\$ 23.124 .045$ & \$ 9.917.470 & $\$ 22.131 .446$ \\
\hline 2015 & $\$ 64.855 .960$ & $\$ 34.525 .541$ & $\$ 3.118 .680$ & $\$ 12.621 .013$ & $\$ 30.330 .419$ & $\$ 39.452 .960$ & $\$ 25.965 .298$ & $\$ 13.487 .662$ & $\$ 25.403 .001$ \\
\hline 2016 & $\$ 68.450 .969$ & $\$ 36.810 .631$ & \$ 2.681 .761 & $\$ 10.904 .493$ & $\$ 31.640 .338$ & $\$ 41.247 .435$ & $\$ 25.590 .568$ & $\$ 15.656 .867$ & $\$ 27.203 .532$ \\
\hline 2017 & $\$ 76.212 .074$ & $\$ 41.287 .902$ & $\$ 2.505 .187$ & $\$ 15.219 .673$ & $\$ 34.924 .172$ & $\$ 45.253 .301$ & $\$ 30.678 .971$ & $\$ 14.574 .331$ & $\$ 30.958 .772$ \\
\hline
\end{tabular}

Note. From "Portal de información", by Superintendence of Companies Securities and Insurance (2018) 
There is a growing trend in asset, liability and equity values. The increase from 2013 to the last year analyzed (2017), is 56,9\%, 57,5\%, and $56.1 \%$ respectively. (See Figure 1).

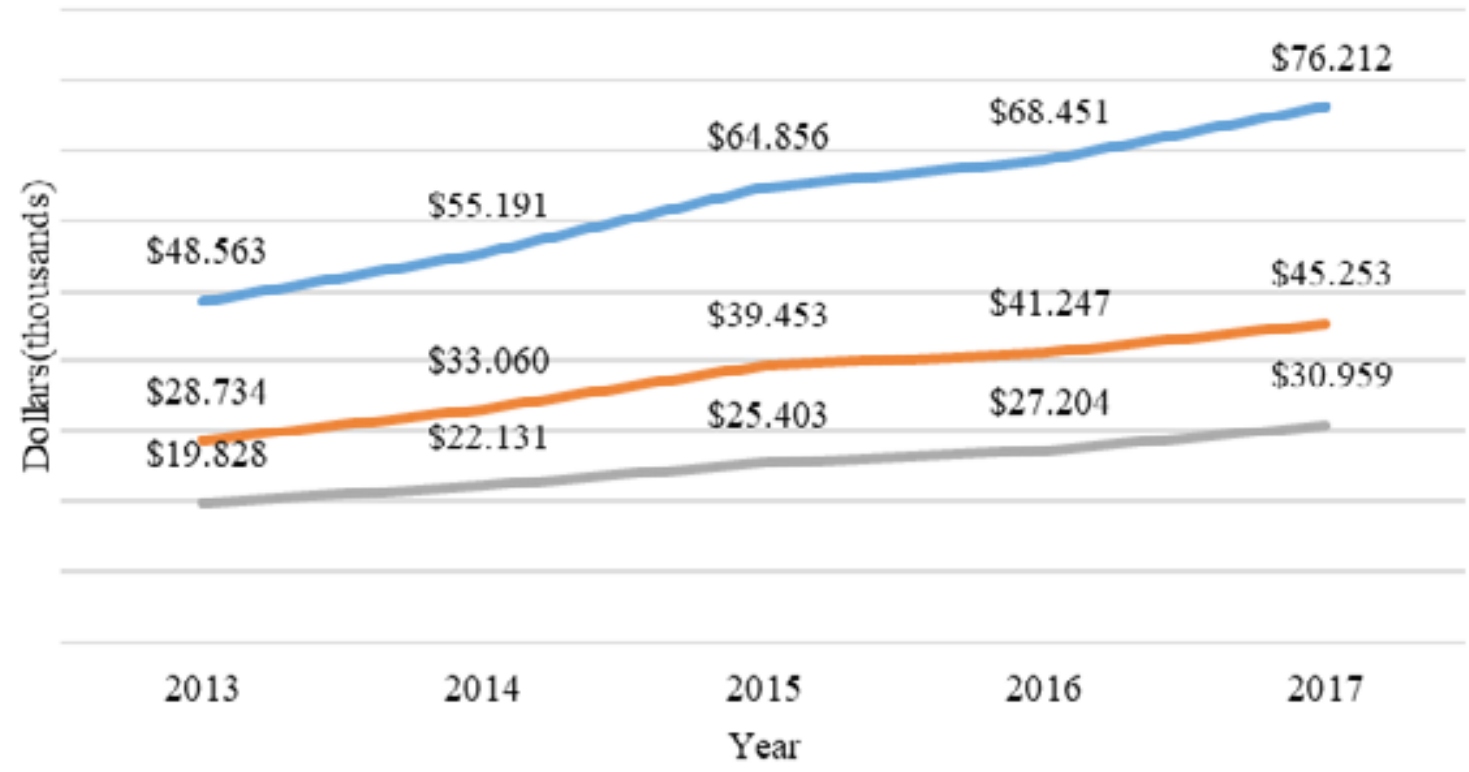

Assets Liabilities —Equity

Figure 1. Asset, liability and equity values of the food manufacturing industry for the period 2013-2017. Data from Superintendence of Companies Securities and Insurance (2018) 


\section{Income statement of the food industry- $\mathrm{C} 10$ companies}

As can be seen in Table 6 , the food manufacturing industry income statement, based on the values of the companies analyzed, is as follows:

Table 6. Food manufacturing industry income statement of the sector for the period 2013-2017

\begin{tabular}{lllllllllll}
\hline \multicolumn{1}{c}{ Year } & & \multicolumn{1}{l}{ Sales } & & Gross profit & $\begin{array}{c}\text { Operating } \\
\text { income }\end{array}$ & EBIT & Net profit \\
\hline 2013 & $\$$ & 106.023 .081 & $\$$ & 23.841 .595 & $\$$ & 5.588 .896 & $\$$ & 4.390 .367 & $\$$ & 3.021 .961 \\
2014 & $\$$ & 117.934 .499 & $\$$ & 27.671 .368 & $\$$ & 4.603 .014 & $\$$ & 4.363 .031 & $\$$ & 3.003 .960 \\
2015 & $\$$ & 127.452 .176 & $\$$ & 30.222 .463 & $\$$ & 6.997 .094 & $\$$ & 4.599 .060 & $\$$ & 3.190 .438 \\
2016 & $\$$ & 127.979 .162 & $\$$ & 33.845 .129 & $\$$ & 8.238 .075 & $\$$ & 7.560 .843 & $\$$ & 5.112 .041 \\
2017 & $\$$ & 142.703 .569 & $\$$ & 35.099 .825 & $\$$ & 7.961 .425 & $\$$ & 7.662 .121 & $\$$ & 5.191 .208 \\
\hline
\end{tabular}

Note. From "Portal de información", by Superintendence of Companies Securities and Insurance (2018)

The sales of the sector likewise reflect a progressive increase in the period. The percentage increases from 2013 to 2017 is $34,6 \%$. (See Figure 2). 


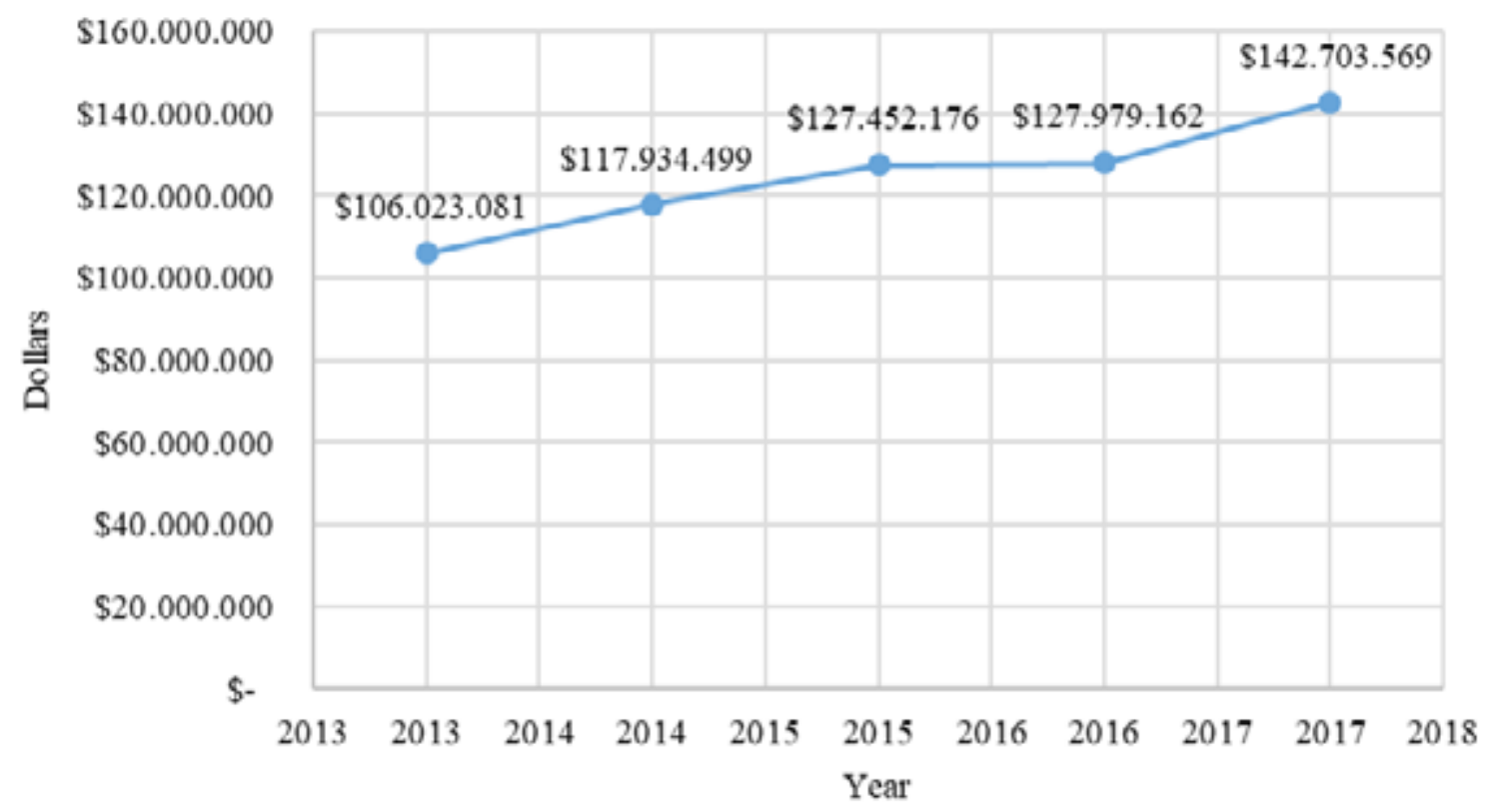

Figure 2. Sales of the sector for the period 2013-2017. Data from Superintendence of Companies Securities and Insurance (2018) 


\section{Classification of companies according to their size}

The classification of companies according to their size, which is established by the Superintendence of Companies, Securities and Insurance (2018b), is as follows. (See Table 7).

Table 7. Classification of companies according to their size

\begin{tabular}{|c|c|c|c|c|}
\hline & Micro enterprise & Small enterprise & enterprise & Large enterprise \\
\hline Workers & 1 - 9 workers & 10 - 49 workers & 50 - 199 workers & More than 200 workers \\
\hline Income & Less than $\$ 100.000$ & $\begin{array}{c}\text { Between } \$ 100.001 \\
\text { and } \$ 1.000 .000\end{array}$ & $\begin{array}{l}\text { Between } \$ 1.000 .001 \\
\text { and } \$ 5.000 .000\end{array}$ & $\begin{array}{c}\text { Higher than } \$ \\
5.000 .001\end{array}$ \\
\hline
\end{tabular}

Note. From "Portal de información", by

Superintendence of Companies Securities and Insurance (2018)

Based on the above information, the classification of the companies analyzed in relation to their size is as follows. (See Table 8).

Table 8. Classification of companies according to their size

\begin{tabular}{c|c|c}
\hline $\begin{array}{c}\text { LARGE } \\
\text { ENTERPRICE }\end{array}$ & $\begin{array}{c}\text { MEDIUM } \\
\text { ENTERPRICE }\end{array}$ & $\begin{array}{c}\text { SMALL } \\
\text { ENTERPRICE }\end{array}$ \\
\hline ITALIMENTOS CÍA LTDA. & DISTRIBUIDORA PERALTA ÁVILA & $\begin{array}{c}\text { FRUTAS VEGETALES CARNES C LTDA } \\
\text { FRUVECA }\end{array}$ \\
\hline LA EUROPEA CÍA LTDA. & PASTIFICIO NILO C LTDA & LACTEOS MILKA LACMILK CÍA LTDA. \\
\hline PIGGI'S EMBUTIDOS PIGEM CÍA LTDA. & ALIMENTOS CHONTALAC CÍA LTDA. & HELADOS LA TIENDA HELATIENDA \\
CÍA LTDA.
\end{tabular}




\section{Application of insolvency risk models}

\section{Application of the Altman Z model \\ (for private manufacturing companies)}

Through the Altman insolvency prediction model, it was determined that the only company that is in bankruptcy risk zone is Company $A$, which is a small enterprise and is shown in Table 9:

Table 9. Z score for the period 2013-2017

\begin{tabular}{lcccccc}
\hline Enterprice & 2013 & 2014 & 2015 & 2016 & 2017 & Risk zone \\
\hline Empresa A & $-0,157$ & $-0,630$ & $-0,310$ & 0,412 & $-0,400$ & Distress zone \\
Empresa J & 1,713 & 1,189 & 1,766 & 2,066 & 2,410 & Grey zone \\
Empresa L & 3,433 & 3,753 & 4,937 & 4,233 & 4,747 & Safe zone \\
Empresa F & 2,935 & 2,496 & 2,930 & 3,445 & 3,950 & Safe zone \\
Empresa C & $\mathrm{N} / \mathrm{D}$ & 5,632 & 6,828 & 6,595 & 3,460 & Safe zone \\
Empresa D & 2,185 & 2,492 & 2,548 & 4,295 & 4,723 & Safe zone \\
Empresa H & 2,526 & 2,849 & 2,842 & 2,788 & 2,879 & Grey zone \\
Empresa K & $\mathrm{N} / \mathrm{D}$ & $\mathrm{N} / \mathrm{D}$ & 4,862 & 8,024 & 7,847 & Safe zone \\
Empresa B & 3,600 & 2,660 & 2,281 & 2,641 & 3,433 & Safe zone \\
Empresa M & 4,082 & 3,715 & 2,935 & 3,595 & 3,346 & Safe zone \\
Empresa I & 3,571 & 3,151 & 2,757 & 2,732 & 2,899 & Grey zone \\
Empresa E & 2,458 & 2,292 & 2,180 & 2,275 & 2,106 & Grey zone \\
Empresa N & 1,860 & 2,530 & 2,165 & 1,663 & 1,910 & Grey zone \\
Empresa O & 2,334 & 2,700 & 2,019 & 2,146 & 2,330 & Grey zone \\
Empresa P & 9,976 & 7,106 & 6,126 & 4,722 & 4,657 & Safe zone \\
Empresa G & 4,098 & 4,071 & 3,995 & 3,375 & 4,870 & Safe zone \\
\hline
\end{tabular}

Note. Risk zone according to Altman's score. The letters represent the companies analyzed. 
There is a decreasing tendency in the levels of insolvency risk of the companies analyzed, except for the year 2014 where there is a value lower than the 5 years analyzed, however, all the values belong to the "Safe Zone", according to the Altman approach. (See Figure 3).

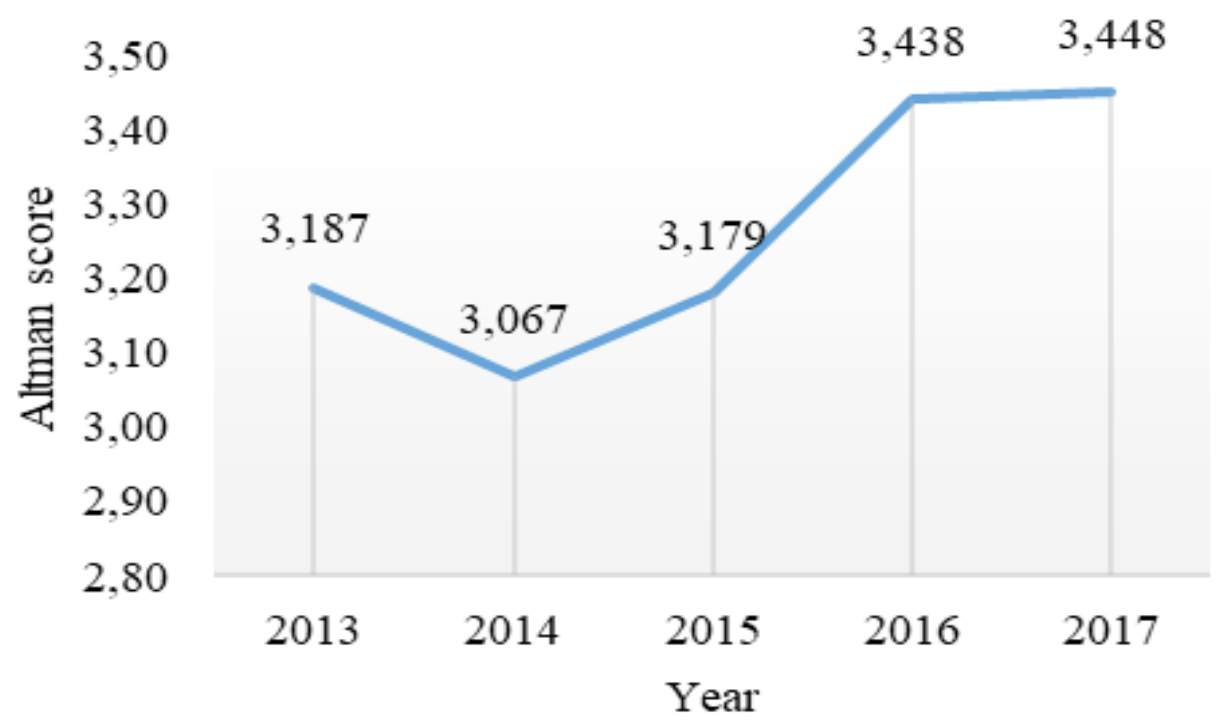

Figure 3. Average business insolvency for the period 2013-2017. Altman methodology.

Based on the average value of $Z^{\prime}$, the following classification of the companies according to their size is obtained, stating that there is no insolvency risk in the three groups analyzed. (See Table 10)

Table 10. $Z$ ' score by company size

\begin{tabular}{|c|c|c|c|c|c|c|}
\hline \multirow{2}{*}{ Size } & \multicolumn{5}{|c|}{ Year } & \multirow{2}{*}{ - Risk zone } \\
\hline & 2013 & 2014 & 2015 & 2016 & 2017 & \\
\hline Large entreprice & 4,158 & 3,636 & 3,143 & 3,043 & 3,036 & Safe zone \\
\hline Medium enterprice & 2,652 & 2,533 & 3,202 & 3,725 & 4,069 & Safe zone \\
\hline Small enterprice & 2,265 & 2,812 & 3,198 & 3,624 & 3,321 & Safe zone \\
\hline Industry average & 3,025 & 2,994 & 3,181 & 3,464 & 3,476 & Safe zone \\
\hline
\end{tabular}


The average of $Z^{\prime}$ score of the food processing sector keeps in values between 2,994 and 3,476, which indicates that the industry, in average finds in "Safe Zone", that is to say that it is not in risk of insolvency. Considering the 5 years analyzed, there is less tendency to fall into insolvency risk, however, large companies have a slight tendency to fall into risk zone. (See Figure 4).

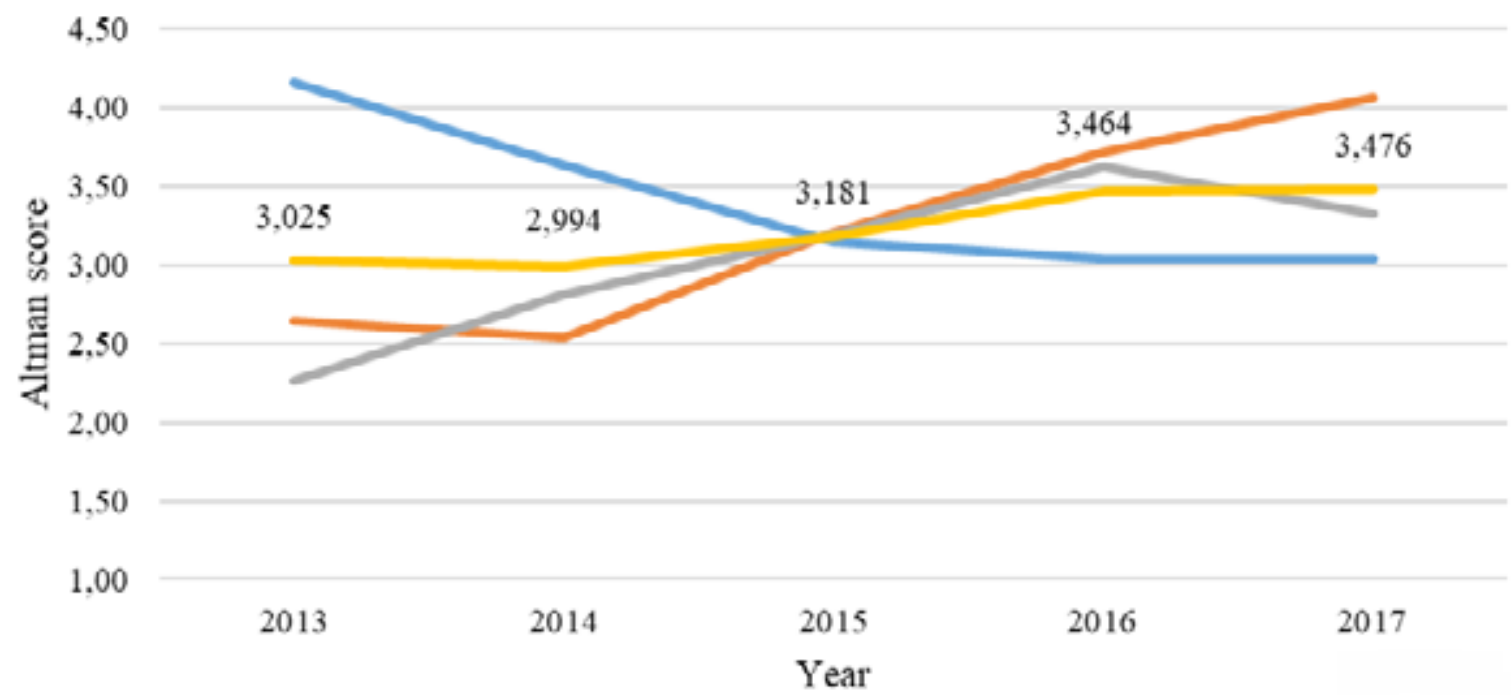

Large enterprise $\longrightarrow$ Medium enterprise $\quad$ Small enterprise $\quad$ Industry average

Figure 4. Z' score variation by company size. Trend analysis. Altman methodology. 


\section{Application of the Ohlson model}

Through the LOGIT model (with the application of the 10 variables mentioned above), it was possible to determine the insolvency risk in the companies analyzed in the period 2013 to 2017. (See Table 11).

Table 11. Probability of business insolvency in the period 2013-2017

\begin{tabular}{|c|c|c|c|c|c|}
\hline Company & 2013 & 2014 & 2015 & 2016 & 2017 \\
\hline A & & $74,76 \%$ & $74,37 \%$ & $74,74 \%$ & $74,48 \%$ \\
\hline B & $18,22 \%$ & $18,40 \%$ & $18,07 \%$ & $13,15 \%$ & $20,58 \%$ \\
\hline C & & $24,52 \%$ & $24,33 \%$ & $22,73 \%$ & $20,25 \%$ \\
\hline D & $18,76 \%$ & $19,26 \%$ & $15,75 \%$ & $15,69 \%$ & $19,35 \%$ \\
\hline E & $12,17 \%$ & $10,03 \%$ & $15,54 \%$ & $13,39 \%$ & $18,66 \%$ \\
\hline F & $17,24 \%$ & $12,50 \%$ & $12,45 \%$ & $15,75 \%$ & $16,40 \%$ \\
\hline H & $17,30 \%$ & $12,66 \%$ & $13,59 \%$ & $13,22 \%$ & $15,46 \%$ \\
\hline I & $19,11 \%$ & $7,58 \%$ & $10,23 \%$ & $12,30 \%$ & $14,55 \%$ \\
\hline J & $11,36 \%$ & $8,64 \%$ & $12,03 \%$ & $10,18 \%$ & $12,51 \%$ \\
\hline K & $11,89 \%$ & $11,29 \%$ & $10,77 \%$ & $9,54 \%$ & $11,65 \%$ \\
\hline L & & & $14,58 \%$ & $14,42 \%$ & $11,58 \%$ \\
\hline M & $75,00 \%$ & $16,13 \%$ & $10,92 \%$ & $10,63 \%$ & $10,72 \%$ \\
\hline N & $11,48 \%$ & $8,76 \%$ & $8,69 \%$ & $12,50 \%$ & $10,53 \%$ \\
\hline O & $19,85 \%$ & $17,41 \%$ & $13,71 \%$ & $9,47 \%$ & $10,14 \%$ \\
\hline P & $12,00 \%$ & $8,88 \%$ & $9,37 \%$ & $9,06 \%$ & $8,86 \%$ \\
\hline Average & $24,40 \%$ & $22,37 \%$ & $18,69 \%$ & $23,58 \%$ & $6,71 \%$ \\
\hline & $20,68 \%$ & $18,21 \%$ & $17,69 \%$ & $17,52 \%$ & $17,65 \%$ \\
\hline
\end{tabular}

Note. Insolvency risk according to Ohlson. The letters represent the companies analyzed.

There is a decreasing trend in the percentage of insolvency risk, which changes from $20.7 \%$ in 2013 to $17.7 \%$ in 2017. (See Figure 5) 


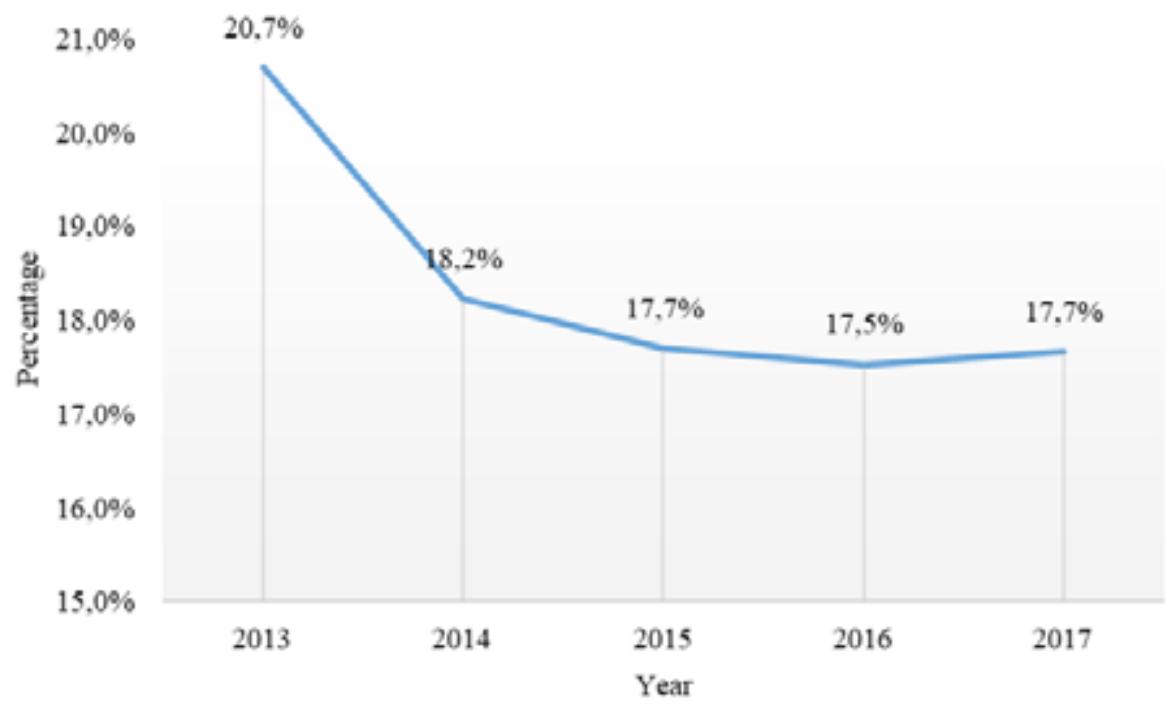

Figure 5. Probability of average business insolvency 2013-2017. Trend analysis. Ohlson methodology.

With respect to business size and insolvency risk, there is a stable trend in the period, mainly as of 2014, since there are no greater variations. Small companies have a higher risk of falling into insolvency, from $17,7 \%$ in 2013 to $29,19 \%$ in 2017. (See Figure 6).

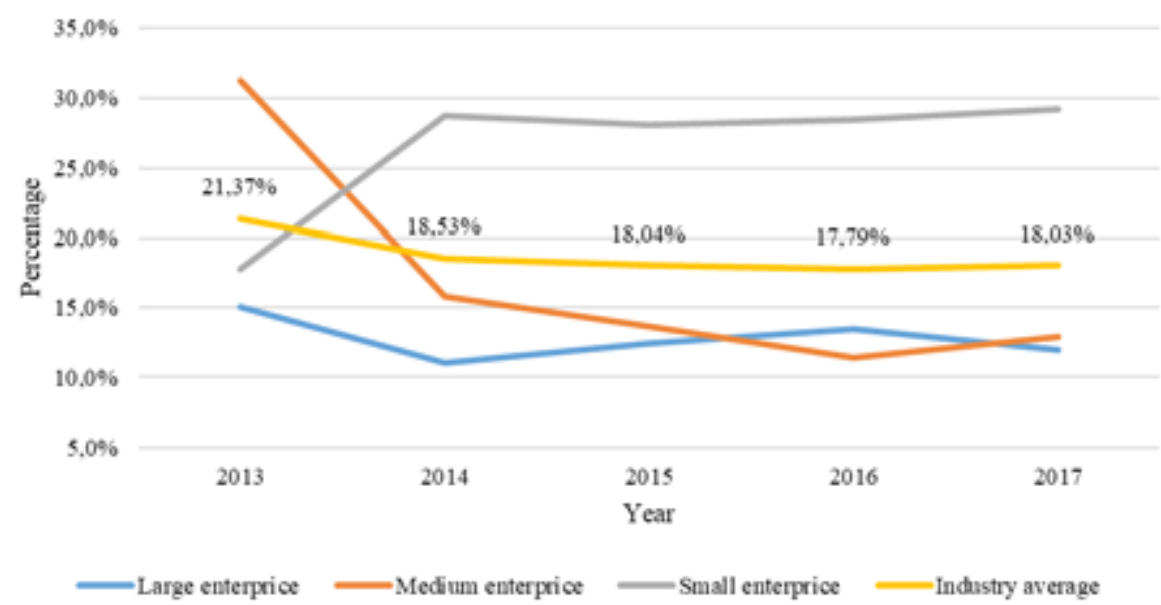

Figure 6. Probability of insolvency by company size period 20132017. Trend analysis. Ohlson methodology. 


\section{Conclusion}

C

urrently there is a changing economic landscape, both nationally and internationally, which requires special attention from the business sector of Ecuador. It must be considered that political, economic, social and technological measures or situations directly or indirectly affect companies, the main economic engine of the countries.

Through the model of prediction of business insolvency of Altman and the probabilistic model of bankruptcy risk proposed by Ohlson, it was possible to determine that the food manufacturing industry in Cuenca is not currently in an insolvency risk zone; there is even a decreasing tendency of this indicator in the period 2013-2017. These results are related to the values in sales and the main accounts of the balance sheet, which values have an upward trend. The behavior of the insolvency risk, in relation to the size of the company showed that small companies have a higher level of insolvency risk in Ohlson model. In the Altman model, small businesses are also more risky in the beginning of the period, but tend to leave the risk zone.

Analyzing the risk of insolvency in Ecuador is extremely important, considering that in the national territory there is a high rate of companies that go bankrupt annually. By means of the analysis carried out, it will be possible to know the levels of risk of falling into insolvency at the business level, as well as to identify trends in the food sector in relation to this indicator. 


\section{REFERENCES}

Altman, E. (1968). The American Finance Association. The Journal of Finance, 23(1), 589-609. https://doi.org/10.1111/j.1540-6261.1946.tb01544.x

Altman, E. (2000). Predicting financial distress of companies: revisiting the Z - score and Zeta ( ) models. Journal of Banking and Finance, 1(1), 2-54.

Arias, L., Castaño, J., \& Rave, S. (2006). Metodologías para la medición del riesgo financiero en inversiones. Scientia et Technica, 3(32), 275-278. https://doi.org/10.22517/23447214.6311

Bautista, R. (2013). Incertidumbre y riesgos en decisiones de inversión (1.a ed.). Bogotá: Ecoe Ediciones.

Beaver, W. (1966). Financial ratios as predictors of failure. Journal of accounting research, 4(1966), 71-111.

Calderón, E. (2016). Evaluación de los modelos de predicción de fracaso empresarial en el sector manufacturero colombiano en los años 2010-2014 ( tesis de maestría). Universidad Nacional de Colombia, Bogotá D,C.

Central Bank of Ecuador. (2018). Documentos estadísticos. Retrieved from https://www.bce. fin.ec/index.php/component/k2/item/757

Dichev, I. (1998). Is the Risk of Bankruptcy a Systematic Risk? The Journal of Finance, 32(3), $875-900$.

Echemendía, B. (2011). Definiciones acerca del riesgo y sus implicaciones. Revista Cubana de Higiene y Epidemiología, 49(3), 470-481.

FitzPatrick, P. (1932). Average Ratios of Twenty Representative Industrial Failures *. The certified public accountant, 13-18.

Hernández, M. (2014). Modelo financiero para la detección de quiebras con el uso de análisis discriminante múltiple. InterSedes: Revista de las Sedes Regionales, XV (32), 4-19.

Martín, S. (2017). 7 mil empresas ecuatorianas cerraron sus puertas en 2016, último año de gobierno Correa. Retrieved from https://es.panampost.com/sabrina-martin/2017/03/15/ ecuador-7mil-empresas-cerraron/ 
National Institute of Statistics and Census. (2019). Estadísticas. Retrieved from https://www. ecuadorencifras.gob.ec/institucional/home/

Ohlson, J. A. (1980). Financial Ratios and the Probabilistic Prediction of Bankruptcy. Journal of Accounting Research, 18(1), 109. https://doi.org/10.2307/2490395

Ordóñes, F., \& Reyna, L. (2018). Riesgo de insolvencia empresarial en el Ecuador durante el periodo 2012-2016( tesis de grado). Universidad de Cuenca. Cuenca, Ecuador.

Pérez, J., Lopera, M., \& Vásquez, F. (2017). Estimación de la probabilidad de riesgo de quiebra en las empresas colombianas a partir de un modelo para eventos raros. Cuadernos de administración, 30, 7-38. https://doi.org/10.1144

Superintendence of Companies Securities and Insurance. (2018). Portal de información. Retrieved from de https://www.supercias.gob.ec/portalscvs/

Wulandari, A., Norita, \& Iradianty, A. (2014). The Effect of Bankruptcy Prediction Using Ohlson Score Model Towards Stock Returns (Study in Textile and Garment Company Listed in IDX For Year 2010-2014). International Journal of Science and Research (IJSR), 4. 